\title{
LIGHTWEIGHT CONCRETE MAKING ANALYSIS USING MIXED CELLULOSE
}

\author{
Nanang Budi Setyawan.1, Fredy Kurniawan2 \\ Narotama University, Australia \\ nanangbudi1994@yahoo.co.id
}

\begin{abstract}
Development era of globalization has resulted in increasing number of second-hand goods / waste that its existence can be a problem for life in the future. Many things are done in order to recycle paper cement in order to overcome this problem the existence of waste. One way is to use waste paper to be a part of the building. The purpose of this study, to determine the compressive strength and optimum density. Laboratory experimental method uses a variation of $10 \%, 20 \%, 30 \%$ and testing conducted in the form of compressive strength and density. From the test results obtained by the result of decrease in the compressive strength and density. In addition cellulose concrete mix design with variations determined that $10 \%, 20 \%, 30 \%$ resulted in a decrease in the compressive strength of concrete,
\end{abstract}

Keywords: cellulose, compressive strength, density

\section{INTRODUCTION}

Utilization of cellulose paper as the raw material of concrete is one alternative that can be applied to overcome the natural pollution caused by waste paper. One of the manufacture of lightweight concrete is to mensubtitusikan normal aggregate into lightweight aggregates. In this study the normal coarse aggregate is substituted with an aggregate made from waste paper cellulose. In the science of building materials there are several types of materials that are categorized as filler in concrete, such as gravel, cement, cellulose and other filler materials (Moerdwiyono 1997 in Andoyo, 2006).

The addition of cellulose paper material to produce optimum power in normal concrete of compressive strength, tensile strength, and the ability to reduce noise (Eniarti, M., 2010). In addition to the extra material of paper, material foaming agent is expected to create a cavity in the normal concrete when the concrete is mixed so that volume can expand and lighten its weight. This research if it can be developed continuously, it can be mass produced and readily available. Foaming agent was chosen as the added material are easily available and easy to be processed en masse later.

Headings tables and figures 
Paper processing cement (Cellulose) as aggregates, namely, first soak the cement paper approximately 3 months until into pulp. The materials used include the following, which is already in the cement paper process into pulp, which is derived from Lumajang sand, gravel with a size of $10 \mathrm{~mm}$, the added material Foam Aggent and concrete drug brand "ADDITON" type $5 \mathrm{~m}$.

Planning a concrete mixture with a proportion of Trial and Error experimental method with the results as a reference for normal concrete is developed into concrete innovation

Table 1. Objects Formula Test

\begin{tabular}{lccccccc}
\hline \multirow{2}{*}{ Test objects } & Cement & Sand & Gravel & Cellulose & $\begin{array}{c}\text { Foam } \\
\text { Aggent }\end{array}$ & Water & $\begin{array}{c}\text { additon } \\
5 \mathrm{M}\end{array}$ \\
\cline { 2 - 7 } & $(\mathrm{Kg})$ & $(\mathrm{Kg})$ & $(\mathrm{Kg})$ & $(\mathrm{Kg})$ & $(\mathrm{L})$ & $(\mathrm{L})$ & $(\mathrm{L})$ \\
\hline Normal & 500 & 830 & 470 & - & 5 & 200 & 12.5 \\
KC1 (Sand 90\% & 500 & 747 & 470 & 83 & 5 & 200 & 12.5 \\
+ + C 10\%) & & & & & & & \\
Kc2 (Sand 80\% & 500 & 664 & 470 & 166 & 5 & 200 & 12.5 \\
+ C 20\%) & & & & & & & \\
Kc3 (Sand 70\% & 500 & 581 & 470 & 249 & 5 & 200 & 12.5 \\
$+30 \%$ C) & & & & & & &
\end{tabular}

Preparation of test specimens made as many as 24 pieces in the form of cylinders, each made with four variations of the test specimen and six specimen at each variation. The test object in the form of a cylinder having a diameter of $15 \mathrm{~cm}$ and $30 \mathrm{~cm}$ high.

In the mixing stage, coarse aggregate, fine aggregate evenly mixed, prepare the appropriate water mix design and split half the dose to be mixed with Aggent Foam, Foam Aggent stir until foamy and ready for use. Mix the dough mixture of aggregate with the additon of $5 \mathrm{M}$ stir after it was input Aggent Foam mix, stirring until smooth and ready digunakan.Setelah concrete slump testing was done. In the treatment phase of the test object.

Compressive strength testing performed on the test specimen aged 7, 14 and 28 days, after the drying process of care test object. Tests conducted in the laboratory compressive strength of concrete Mektan and Civil Engineering University Narotama.

\section{Equations, formulas and code}

Testing of fine and coarse aggregates include moisture, density, volume weight, hygiene, sieving, as the following table;

Table 2. Aggregate testing

\begin{tabular}{lcc}
\hline \multicolumn{1}{r}{ This type of testing } & Smooth & Rude \\
\hline humidity sand & $1.7 \%$ & $0.5 \%$ \\
\cline { 2 - 3 } Bulk specific gravity & $2: 39$ & $2: 35$ \\
\hline
\end{tabular}


Volume 2 Number 2 March 2019

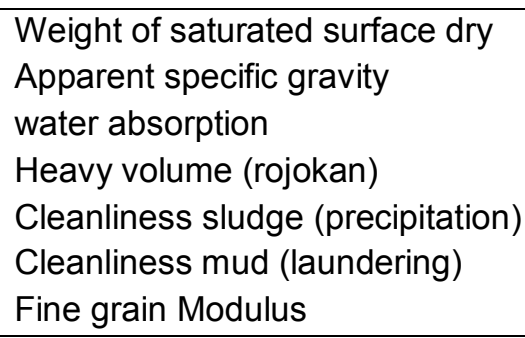

In testing the compressive strength, compressive strength is obtained as follows;

Table 3. Results Density and Compressive Strength

\begin{tabular}{|c|c|c|}
\hline test specimen & $\begin{array}{c}\text { Specific gravity } \\
\text { Average } \\
(\mathrm{Kg} / \mathrm{m} 3)\end{array}$ & $\begin{array}{l}\text { compressive } \\
\text { strength } \\
\text { Average } \\
(\mathrm{Kg} / \mathrm{cm} 2)\end{array}$ \\
\hline Normal & $\begin{array}{c}2374 \text { ( } 7 \text { days) } \\
2388 \text { (14 days) } \\
2393 \text { (28 days) }\end{array}$ & $\begin{array}{c}135.46 \text { ( } 7 \text { days) } \\
154.57 \text { ( } 14 \text { days) } \\
208.76 \text { ( } 28 \text { days) }\end{array}$ \\
\hline KC1 (Sand $90 \%+C 10 \%$ ) & $\begin{array}{r}2151 \text { ( } 7 \text { days) } \\
2191 \text { ( } 14 \text { days) } \\
2232 \text { ( } 28 \text { days) }\end{array}$ & $\begin{array}{c}134.42 \text { ( } 7 \text { days) } \\
149.7 \text { (14 days) } \\
207.02 \text { ( } 28 \text { days) }\end{array}$ \\
\hline Kc2 (Sand $80 \%+C 20 \%$ ) & $\begin{array}{c}1864 \text { (7 days) } \\
1889 \text { (14 days) } \\
1927 \text { (28 days) }\end{array}$ & $\begin{array}{c}96.56 \text { ( } 7 \text { days }) \\
109.41 \text { ( } 14 \text { days }) \\
148.31 \text { ( } 28 \text { days })\end{array}$ \\
\hline Kc3 (Sand $70 \%+30 \%$ C) & $\begin{array}{c}1552 \text { ( } 7 \text { days) } \\
1583 \text { (14 days) } \\
1612 \text { (28 days) }\end{array}$ & $\begin{array}{c}66.34 \text { (7 days) } \\
80.23 \text { (14 days) } \\
105.24 \text { (28 days) }\end{array}$ \\
\hline
\end{tabular}

Graph 1. Compressive Strength Test Objects

\begin{tabular}{|c|c|c|c|c|}
\hline 250 & \multicolumn{3}{|c|}{ Tes tekan hancur silinder $(\mathrm{kg} / \mathrm{cm} 2)$} & \\
\hline \multicolumn{5}{|l|}{200} \\
\hline \multirow{2}{*}{\multicolumn{5}{|c|}{150}} \\
\hline & & & & \\
\hline \multicolumn{5}{|l|}{50} \\
\hline 0 & Normal & K.C 1 & K.C 2 & K.C 3 \\
\hline Tes tekan 7 hari & 135,46 & 134,42 & 96,56 & 66,34 \\
\hline Tes tekan 14 hari & 154,57 & 149,7 & 109,41 & 80,23 \\
\hline Tes tekan 28 hari & 208,76 & 207,02 & 148,31 & 105,24 \\
\hline
\end{tabular}


A normal concrete compressive strength is an average of $166.26 \mathrm{~kg} / \mathrm{cm} 2$. The test object (KC1) with a mixture of cellulose proportion of $10 \%$ of the weight of sand compressive strength of $163.71 \mathrm{~kg} \mathrm{/} \mathrm{cm} 2$, the addition of cellulose by $20 \%$ (Kc2) and the result is decreased by $118.09 \mathrm{~kg} / \mathrm{cm} 2$. While the specimen (Kc3) with a proportion of $30 \%$ cellulose has a compressive strength of $83.93 \mathrm{~kg} / \mathrm{cm} 2$. It can be concluded that with increasing variation of cellulose $(10 \%, 20 \%$ and $30 \%)$ to the weight of the sand, the weight loss at the same time a decrease in compressive strength of concrete.

\section{Quality Relationship with Weight}

Quality relationship with weight is equal compressive strength (fc ') divided by density $(\mathrm{kg} / \mathrm{m} 3)$. The equation to determine an efficient compressive strength against weight. The more lightweight concrete with high compressive strength value then becomes the ideal value.

\begin{tabular}{|c|c|c|c|}
\hline $\begin{array}{c}\text { age of } \\
\text { concrete }\end{array}$ & $\begin{array}{c}\text { Compre } \\
\text { ssive } \\
\text { strength } \\
\text { (Fc ') }\end{array}$ & $\begin{array}{c}\text { Specific } \\
\text { gravity } \\
\text { (Kg / cm2) }\end{array}$ & $\begin{array}{c}\text { Compressive } \\
\text { strength / } \\
\text { Density (fc) (kg } \\
\text { / cm2) }\end{array}$ \\
\hline \multirow{3}{*}{ Normal } & 204.94 & 2393 & 0,085 \\
\cline { 2 - 4 } & 212.58 & 2394 & 0088 \\
\hline \multirow{3}{*}{ KC 1 } & 200.77 & 2242 & 0089 \\
\hline \multirow{3}{*}{ KC 2 } & 213.27 & 2223 & 0.095 \\
\cline { 2 - 4 } & 137.55 & 1914 & 0071 \\
\hline \multirow{2}{*}{ KC 3 } & 159.08 & 1940 & 0082 \\
\cline { 2 - 4 } & 115.32 & 1610 & 0059 \\
\hline
\end{tabular}


The results of the testing of compressive strength and unit weight of the concrete can be seen in the following table:

Table 4. Relationship Between Compressive Strength And Density

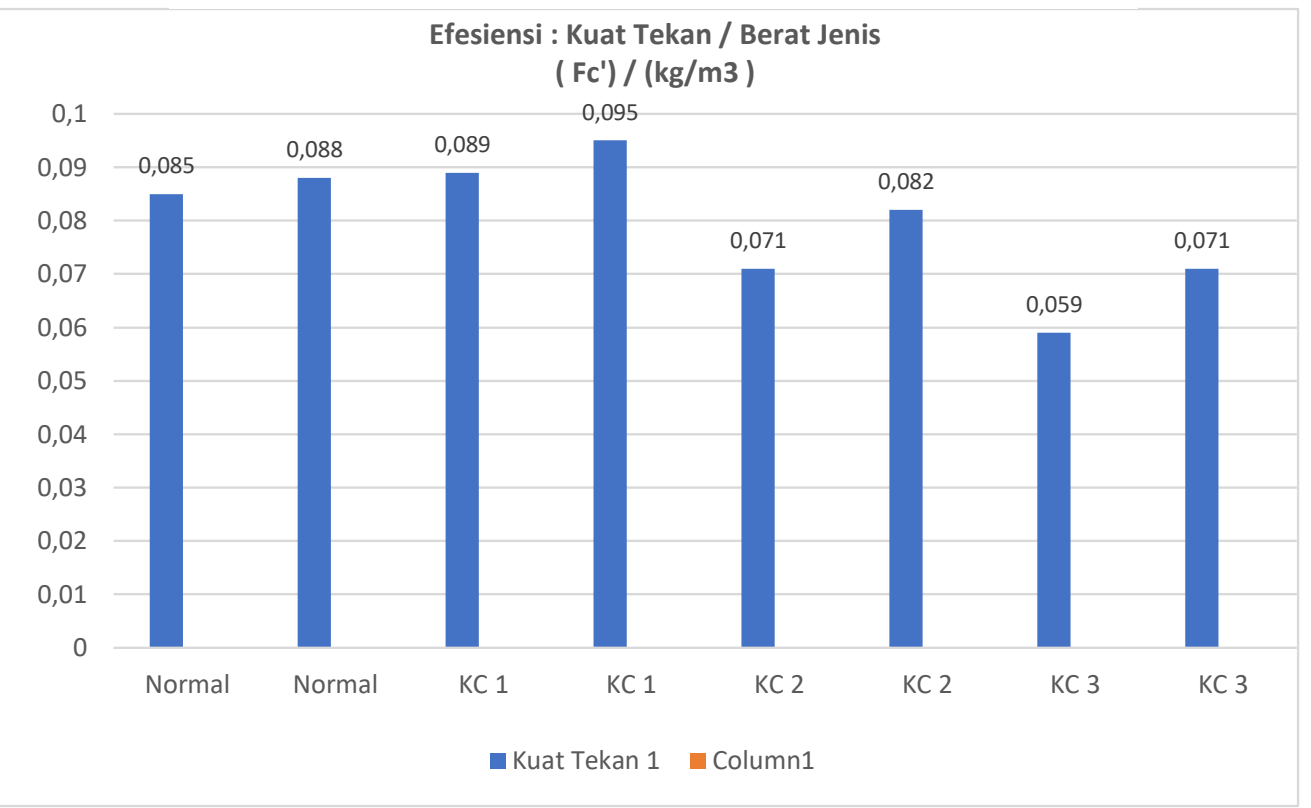

Graph 2. the relationship between the compressive strength and density

Based on the chart 2 shows that the composition of the material that was done the appropriate mix design, namely cement, Lumajang sand, gravel, foarm agent, water, and adding 5M Cellulose Addition on MixDesign quality Concrete K.200, with the same quality mix design, there are two variations, namely normal concrete and concrete using cellulose in addition cellulose concrete mix design with variations determined that $10 \%$, $20 \%, 30 \%$ can be concluded that the mix design KC.1 (concrete with a mixture of cellulose $10 \%$ ) who have a compressive strength with density the ideal is cellulose $10 \%$ with a value of 0095 , while the low value that is concrete mix design with cellulose KC.3 $30 \%$ by 0059 and by 0085 concrete K200 nomal.

\section{Footnotes and acknowledgements}

On the results of research and discussion that has been done can be some conclusions as follows:

1. Effect of waste paper as a fine aggregate cement concrete is made to be mild but when its use becomes excessive eating compressive strength drop or lower. 
Volume 2 Number 2 March 2019

2. Cylinder compressive strength testing results have shown that the material composition mix design is done in accordance cellulose, additon $5 \mathrm{M}$, foam agent makes the compressive strength and density of concrete to be mild. The more the composition of the cellulose material mixing light concrete influence on the strength of concrete in the concrete age of 28 days in lightweight concrete (KC3) compressive strength of $115 \mathrm{~kg} / \mathrm{cm} 2$ decreased $10 \%$ compressive strength of normal concrete compressive strength of $212 \mathrm{~kg} / \mathrm{cm} 2$

3. Compressive Strength average of the highest concrete with a concrete mixture sellulose achieved by the composition of the additon of $5 \mathrm{M} 2.5 \%$ of cement, foam Agent $1 \%$ of cement, sellulose $10 \%$ of sand of $213 \mathrm{~kg} / \mathrm{cm} 2$.

4. On Early Stage to aggregate and material preparation plan should be ensured to be clean from mud and placed in a safe place until the aggregate and the material is ready for use

5. For Paper Material Fine Aggregate Cement lieu though preferably should be in advance and note the water level because the paper must be wet cement should not contain a lot of water For Lightweight Concrete Curing Treatment cellulose composition should not be put into a water / soaked due to the drying process takes a long time.

6. Based on the above conclusions after conducting research and to test the concrete compressive test, there was a decrease in the average compressive strength of the concrete with the addition of $5 \mathrm{M} 2.5 \%$ foam agent $4 \%$ to $30 \%$ of cement sellulose this happens is because if the addition of $2.5 \%$ foam agent addition $4 \%$ sellulose $30 \%$ too many numbers are not good also for the quality of concrete in achieving the targets.

7. And also there should be studies further research on the concrete with a mixture of addition of $5 \mathrm{M}$, foam agent, sellulose with a different composition and calculation mix disegn another although in this study can already be known to the compressive strength of concrete the most optimum of some mix disegn in order to determine the composition a mixture of $5 \mathrm{M}$ addition, foam agent, sellulose more precise in the manufacture of high quality concrete. In order to obtain maximum results and time can also be accepted in a concrete industry according to SNI (Indonesian National Standard)

\section{REFERENCES}

Asroni, A., (2010), Foundations Columns And Beams T Concrete, Surakarta: Graha Ilmu.Aji, EW, (2016), Anonymous (2013),

Asroni, A., (2010) "Utilization of Waste Paper To Making Papercrete Panel", Forum of Civil Engineering No. XVIII / 2-May 2008, Yogyakarta. Honing, J.1982, Steel building, Pradaya Paramita. Jakarta

Asroni, A., (2010), Foundations Columns And Beams T Concrete, Surakarta: Graha IImu.Aji, EW, (2016), Anonymous (2013), 
ASTM C.1240-01 " Standard Specification for Use of Silica Fume as a Mineral adhimixture in Hydraulic Cement Concrete and Mortar " Annual Book of ASTM Standards, USA, 2002

ASTM C.330, "Standard Specification for Lightweight Aggregates for Structural Concrete" Annual Book of ASTM Standards, USA, 2002

ASTM C.39-01 "Standard Test for Compressive Strength of Cylindrical Concrete " Annual Book of ASTM Standards, USA, 2002

ASTM C.78-02 " Standard Test Method for Flexural Strength of Concrete (Using Simple Beam with Third-Point Loading) 'Annual Book of ASTM Standards, USA, 2002

Bermansyah, S., Huzaim, and Hevianis, Sanneti., 2011, "Analysis of the proportion of sand Against Pulp and Paper Concrete Compressive Strength", Proceedings of the National Seminar on Regional Infrastructure Technology Applications, 2011, ISBN: 978-979-18342-3-0, Surabaya.

SW Mudjanarko, A Alimudin, E Setiawan, G Arimbawa., 2017 " Enginering Technology of Bamboo Materials and Additive Foam as Mixed Concrete Paving Materials Production and superb on " Journal Lantern: Religious Studies, Scientific and Technology. 